\title{
Judicial Analysis of the Constitutional and Procedural Safeguards against Arbitrary Arrest and Detention
}

\author{
Deepthi B*
}

\section{Abstract}

Right to life under Article 21 of the Indian Constitution has been accorded a paramount status by the judiciary. Article 21 and 22 of the Constitution envisages detailed safeguards against arbitrary arrest and detention. The judiciary, in a series of cases, has examined at length these safeguards in the larger context of the power of the executive to apprehend persons who are suspected of having committed crimes. This paper makes an in depth analysis of the judicial pronouncements relating to the power of the executive to arrest. The paper also analyses the amendments made in the year 2008 to the Criminal Procedure Code 1973. The concept of compensatory jurisprudence laid down by the Supreme Court in cases of arbitrary deprivation of life and liberty under Article 21 of the Constitution is also assayed.

Keywords: Arbitrary Arrest, Code of Criminal Procedure 1973, Compensatory Jurisprudence, Constitution, Right to Life

\section{Introduction}

"No arrest can be made because it is lawful for the police officer to do so. The existence of the power of arrest is one thing and the justification for the exercise of such power is quite another." 1 This

\footnotetext{
* Second Year, BA LLB, The West Bengal National University of Juridical Sciences, Kolkata, West Bengal; bdeepthi15@gmail.com.

${ }^{1}$ Joginder Kumar v. State of U.P., A.I.R. 1994 S.C. 1349.
} 
statement was made in the third report of the National Police Commission wherein it was observed that the power of arrest was a major source of corruption in the police. ${ }^{2}$ Arrest is essentially the apprehension of a person by a legal authority resulting in the deprivation of his personal liberty. ${ }^{3}$ Article 21 of the Constitution of India stipulates that no person shall be deprived of his life or personal liberty except in accordance with the procedure established by law. In Maneka Gandhi v. Union of India ${ }^{4}$ it was laid down that such procedure must be just, fair and reasonable. Thus, by inference it is established that procedural laws must not be arbitrary or oppressive. In this article the author analyses the provisions of the Code of Criminal Procedure 1973 (CrPC 1973) relating to arrest. The tortious liability of the state, the evolution of compensatory jurisprudence and the concept of anticipatory bail in lieu of arrest are also debated in the article.

The first part of this article, states the various provisions of $\mathrm{CrPC}$ 1973 that enable a police officer to arrest an individual. This is followed by a brief analysis of the procedural safeguards provided in the Constitution against the deprivation of personal liberty by arrest. The third part of the article discusses how the discretionary power to arrest is grossly misused by the police forces. Lastly, the article deals with the recommendations that were issued by the National Police Commission in order to regulate the abuse of the power of arrest. The judiciary has also taken cognizance of this problem and issued guidelines in the landmark cases of D.K. Basu v. State of West Bengal ${ }^{5}$ and Siddharam Sathilingappa Mhetre v. State of Maharashtra. ${ }^{6}$ The legislature finally took into account these recommendations made by the judiciary and incorporated them into CrPC 1973 by means of the CrPC Amendment Act 2008.

2 Law Commission of India, Consultation Paper on Law Relating to Arrest, available at http://lawcommissionofindia.nic.in/reports/177rptp2.pdf11 (last visited Apr. 9, 2013).

${ }^{3}$ DR. K.N. ChandrasheKaran Pillai, R.V. KelKaR's LeCtURES ON CRIMINAL PROCEDURE 21 (Eastern Book Company $4^{\text {th }}$ ed. 2003).

${ }^{4}$ A.I.R. 1978 S.C. 597.
${ }^{5}$ A.I.R. 1977 S.C. 416.
${ }^{6}$ A.I.R. 2011 S.C. 312. 


\section{Legal Provisions relating to the Executive's Power of Arrest}

The law relating to the arrest of individuals is discussed in Chapter V of the CrPC 1973. Section 41 of the Code lays down the different circumstances under which the police may arrest a person without a warrant. Under this provision, a person can be arrested without a warrant if he is a proclaimed offender. Similarly, if someone is reasonably suspected of being a deserter from the armed forces of the union, he can be arrested without the issuance of a warrant. This provision is also invoked for arresting a person who has escaped or attempts to escape from the lawful custody of a police officer. Thus, Section 41 lays down the circumstances under which a person's liberty can be curtailed by means of arrest. Under this section, a police officer may arrest a person without a warrant if the police officer comes to know that the person is about to commit any cognizable offence. ${ }^{7}$ Further, Section 42 of the Code also provides for arrest of a person by a police officer. Under this provision, a police officer has the authority to arrest a person if he refuses to divulge the details of his name or place of residence. In addition to this, police officers are also invested with the power of preventive detention under Section 151 of CrPC 1973.

\section{Constitutional Safeguards against Arbitrary Arrest}

The Constitution of India provides several safeguards against arbitrary arrest. Article 22(1) states that a person detained in custody shall be informed as soon as possible of the reasons for his arrest. It also states that the accused shall not be denied the right to consult a legal practitioner of his choice. Article 22(2) further adds that such a person should be produced before the nearest magistrate within 24 hours of the arrest. It also states that a person cannot be detained in custody for more than 24 hours without the permission of the magistrate. This acts as a method for keeping check on the arbitrary powers of the police.

7 Sunil Goel, Courts Police, Authorities \& Common Man 122 (Shrishti Books $1^{\text {st }}$ ed. 2005). 


\section{Abuse of the Power of Arrest by the Executive}

Although there are safeguards against arbitrary arrest in both the CrPC 1973 and the Constitution, the power of arrest is abused by the executive. For instance, under Section 41(1)(a) of the CrPC 1973 a police officer may arrest a person without a warrant if he has committed any cognizable offence. This corresponds to the definition of cognizable offence that is stated in Section 2(c) of CrPC 1973. The definition reiterates that a cognizable offence is an offence where a police officer may arrest a person without a warrant. The key word used here is 'may'. The inclusion of the word 'may' confers discretionary powers on the police officers. The other provisions of Chapter V of the CrPC 1973 are also couched in similar generic terms.

In Nandini Satpathy v. PL Dani, 8 the Supreme Court remarked that an ideal balance has to be struck between protecting the rights of the individual on the one hand, and the rights of the society at large on the other. Over the years, it has been observed that the rights of the accused have been accorded better protection. This is the norm in the international context as well. ${ }^{9}$ In the case of Joginder Kumar v. State of UP,10 a twenty year old lawyer was detained by the police for a number of days. A writ of habeas corpus was filed under Article 32 of the Constitution of India. It was found that there was no case against him and he was merely arrested in connection with an investigation in another case. The Supreme Court condemned the police, as personal liberty was curtailed without observance of due process of law. In the course of awarding the judgement, the court found that more than $60 \%$ of the arrests in the country were unnecessary and completely unjustified. Furthermore, it was found that such arrests came at a substantial cost to the exchequer and accounted for $43.2 \%$ of the jail expenditure.

\footnotetext{
${ }^{8}$ A.I.R. 1978 S.C. 1025.

${ }^{9}$ Miranda v. Arizona, 384 U.S. 436 (1966).

${ }^{10}$ A.I.R. 1994 S.C. 1349.
} 


\section{Recommendations of the National Police Commission to Check Arbitrary Arrest by the Executive}

The National Police Commission in its third report stated that no arrest should be made simply on the basis of allegations. ${ }^{11}$ It suggested that the police should ensure that arrest should be made only after ensuring that the complaint is genuine. Furthermore, the police must take into consideration whether there is a need for arrest. The need for arrest arises only in the case of commission of grave offences. Arrest can also be done when it is felt that the accused will abscond and his presence is necessary for conducting the trial. Any person can be arrested if it is apprehended that he will hamper the smooth functioning of justice by tampering with the witnesses. ${ }^{12}$

\section{Judicial Pronouncements Relating to Arbitrary Arrest}

An arrested person being held in custody is entitled to inform a friend or relative about his arrest. Furthermore, the existence of this right should be communicated by the police to the accused at the time of his arrest. In order to ensure that these safeguards have been followed, a case diary is to be maintained under Section 172 of CrPC 1973. A duty is then cast upon the magistrate to ensure that these safeguards are complied with by the police.

A set of further guidelines were issued in D.K. Basu v. State of West Bengal13 $^{13}$ as there was no specific legislation to curtail the power of the police. This was done in pursuance of the International Convention of Civil and Political Rights 1966 which India ratified in 1979. The Supreme Court emphasised on adherence to these guidelines in pursuance of Articles 141 and 142 of the Constitution of India which enables it to do complete justice. Until a proper legislation is drafted, the guidelines were to operate as a part of the law of the land. These guidelines are discussed in detail in the following paragraphs.

${ }^{11}$ Law Commission of India, supra note 2.

12 Law Commission of India, supra note 2.

${ }^{13}$ A.I.R. 1977 S.C. 416. 


\section{Identification of the Police Personnel}

It is stated that when the police carry out the arrest they should carry accurate, visible and clear identification which certify that they belong to the police force. The details of the police personnel in charge of interrogation should be then recorded in a register.

\section{Memorandum of Arrest}

The police officer carrying out the arrest shall then prepare a memorandum of arrest. This must contain the date, time and place of the arrest. This must be attested by at least one person residing in that locality such as the neighbour. This attestation can also be done by a friend or a relative. The person who is arrested then has to counter sign this memorandum so as to cross check its contents. A person who is arrested or detained is entitled to inform one friend or relative who is interested in his welfare. This is done so that the relative or friend can take appropriate legal steps for the release of the person. If the friend or the relative is staying outside the jurisdiction of the police station, then the police officer must notify the location of such police station. The time and place of arrest must be duly communicated to the friend or relative within eight to twelve hours after the arrest.

\section{Case Diary}

An entry relating to any arrest must be made in the case diary, which is to be maintained by the investigating officer. When the arrested person is brought before the magistrate within twenty four hours, the magistrate will examine the contents of the case diary so as to ensure that all the safeguards are complied with.

\section{Inspection Memo}

If the arrested person is to be examined then all the major and minor injuries that are present on his body at the time of arrest must be recorded in an inspection memo. This memo must then be signed by both the police officer and the arrested person. The purpose of this inspection memo is twofold. Firstly, the record of 
bruises suffered by the accused can help assist in proving the innocence of the accused. Secondly, this prevents the police personnel from inflicting injuries upon the accused in order to extract information from him. However, unlike the other legal rights that have to be informed to the accused upon the time of his arrest, the right to inspection is not mandatory.

\section{Medical Examination of the Arrested Person}

While the arrested person is in custody, he must be subjected to a medical examination once in every forty eight hours during his arrest. This examination must be conducted by a trained doctor. This examination is done to assess the physical and mental condition of the person. This is to ensure that the police does not apply third degree methods on the arrested person. Thus, this provision acts as a check on the arbitrary exercise of powers by the police.

\section{Right to Legal Aid}

The arrested person is allowed to meet his lawyer during his interrogation. However, the lawyer cannot be present throughout the interrogation. If the arrested person is not equipped with the adequate facilities for procuring a lawyer, then the State will assist him in doing so. This is done to ensure that the basic principles of natural justice are complied with. The copies of all the documents are then sent to the nearest magistrate. This is done in order to minimise the abuse of the discretionary power of the police. Thus, this prevents the abuse of power by the police and protects the personal liberty of the individual.

\section{Police Control Room}

A police control room should be set up in every district headquarters. Information regarding the arrest and place of custody of each arrested person should then be put up in a conspicuous place in the police control room. This is done in order to assist the kith and kin of the accused when the accused is arrested in another jurisdiction. These details also help those who 
are contemplating filing a habeas corpus petition. On the failure to obtain the details of the accused from such list, the relatives or friends of the accused can then file a writ petition demanding to know the particulars of the accused. Failure to comply with these guidelines would make the police officer in charge subject to departmental action. He would also be held guilty for contempt of court. These guidelines have the same enforceability as those issued by the National Police Commission.

\section{Code of Criminal Procedure (Amendment) Act 2008}

In the year 2008, several amendments were made to the CrPC 1973 especially in relation to arrest. The various guidelines that were specified in D.K. Basu v. State of West Bengal14 case were incorporated into the legislation by virtue of these amendments. Section 41 A of the CrPC 1973 provides that a police officer instead of arresting the person concerned can instead merely issue a notice of appearance to him. Section 41B of the CrPC 1973 lays down the procedure for arrest and duties of the officers making the arrest. These duties are the same as those that were laid down in D.K. Basu v. State of West Bengal. ${ }^{15}$ Section $41 \mathrm{C}$ of the Code requires the state to set up a police control room in every district and at the state level. Thus, all the amendments closely reflect those that were specified in D.K. Basu v. State of West Bengal.16

Some special provisions were made so as to prevent the abuse of the exercise of arbitrary powers by the police especially with regard to women. For instance, it has been specified under Section 46(4) of the CrPC 1973 that no woman will be arrested before sunrise and after sunset. If the circumstances are such that the woman needs to be arrested immediately, then such arrest must be conducted by a woman officer. Such arrest must be conducted with the prior permission of the judicial magistrate.

Furthermore, when a woman is being arrested, unless circumstances point towards the contrary, the intimation of her

\footnotetext{
${ }^{14}$ A.I.R. 1977 S.C. 416.

15 A.I.R. 1977 S.C. 416.

${ }^{16}$ A.I.R. 1977 S.C. 416.
} 
arrest itself is a presumption of her submission. This presumption has been made under proviso to Section 46(1) of the Code of Criminal Procedure (Amendment) Act 2008. The police officer will not touch the body of the woman unless the officer is a woman. If the arrested woman resists then only the police can use the required force to effectuate the arrest. These provisions for women have been made in pursuance of Article 15(3) of the Constitution which allows special provisions to be made for women to ensure equality. These provisions ensure that the power is not abused by police officers so as to perpetuate violence against women.

\section{Tortious Liability of the State and Compensatory Jurisprudence}

The Supreme Court has developed the principle of compensatory jurisprudence where, if a person has been arbitrarily arrested and subsequently harassed by the police, then the state has to compensate such individuals. Such victims of police atrocities are awarded compensation by virtue of Article 21 of the Constitution. This principle of compensatory jurisprudence is derived from the Universal Declaration of Human Rights 1948 and Article 9(5) of the International Covenant on Civil and Political Rights 1966.

The Supreme Court first addressed the issue of tortuous liability of the state in the case of Kasturilal v. State of UP. ${ }^{17}$ In this case, the gold that was in possession of the accused were seized from him and kept in the security deposit of the police station. These gold articles were later misappropriated by a police officer. Later, it was found that the accused was wrongly arrested and he was released by the police. However, the gold was not restored to him. The court stated that no suit can exist with respect to tortious acts of government servants as these acts are done in exercise of sovereign powers of the state. Reliance was placed on Article 300 of the Constitution which talks about the states' right to sue and to be sued. No compensation was paid as the court invoked the power of sovereign immunity as the police officer was discharging an official duty.

${ }^{17}$ A.I.R. 1965 S.C. 1039. 
The first case in which compensatory jurisprudence was effectively laid down is the Bhagalpur Blinding18 case. In this case a person had been blinded and tortured by the police and as a result of which he lost his vision. The blindness was found to be incurable. The Supreme Court held that this was the worst form of violation of fundamental rights, under Article 21 of the Constitution of India. The Supreme Court then directed the state to award him compensation immediately. This decision of the Supreme Court was affirmed later in the case of Rudul Shah v. State of Bihar. ${ }^{19}$ In this case, an under trial was found languishing in jail for a duration of fourteen years. The court ruled that he had lost considerable period of his life due to a wrong decision of the government. Taking into account the long period of time that he had suffered in jail, the court awarded him a generous compensation under Article 21 of the Constitution of India.

However, the Supreme Court later clarified in the case of M.C. Mehta v. State of Bihar ${ }^{20}$ as to whether compensation would be awarded as a norm in each and every case. The apex court stated that compensation will be granted under Article 21 of the Constitution only in real and exceptional cases, where it is evident that fundamental rights have been violated by the police. The court would first satisfy itself that the individual cannot be adequately compensated through any other means and that he requires immediate financial assistance. The case of Nilabati Behra v. State of Orissa $^{21}$ is illustrative of such an exceptional case. In this case, the deceased succumbed to injuries caused due to police torture. The body was subsequently recovered from the railway tracks in an attempt to disguise it as a suicide. The mother of the deceased approached the court and she was granted compensation. In addition to receiving compensation under Article 21 of the Constitution, an individual can also seek additional remedies under other laws. For instance, if a person has been falsely implicated in a case then compensation will be awarded to him on

\footnotetext{
${ }^{18}$ Anil Yadav v. State of Bihar, A.I.R. 1982 S.C. 1008.

${ }^{19}$ (1983) 4 S.C.C. 141.

${ }^{20}$ (1987) 1 S.C.C. 395.

${ }^{21}$ A.I.R. 1993 S.C. 1960.
} 
the basis of section 357 of the CrPC 1973. In addition to this, he can also opt for compensation by means of filing a civil suit. In Sube Singh v. State of Haryana 22 it was held that an award of compensation under Article 21 of the Constitution will not come in the way of an aggrieved party claiming additional compensation in civil court or under Section 357 of the CrPC 1973.

One criticism of the principle of compensatory jurisprudence is that the financial burden has to be borne by the public exchequer. ${ }^{23}$ However, it must be noted at this stage that the evolution of the principle of compensatory jurisprudence has helped to curtail the arbitrary power that has been exercised by the police.

\section{Anticipatory Bail}

Anticipatory bail is obtained in anticipation of arrest. This provision has been added to the CrPC 1973 by virtue of Section 438 of the CrPC 1973. This bail is granted by the Sessions Court or by the High Court. It is granted on the basis that the accused is a reasonable man and he does not want his reputation to be tarnished in the society. An application for anticipatory bail is made if the individual has a reasonable apprehension that he will be arrested at any point of time. M.C. Abhraham v. State of Mahrasthra ${ }^{24}$ is an important decision that discusses about the discretionary power of the police vis a vis the granting of anticipatory bail. In that case many directors of a company were implicated in a case of criminal breach of trust. The company had not deposited the provident funds of employees. The director of the company then approached the High Court for anticipatory bail. The court refused to grant anticipatory bail taking into account the severity of the offence. The court laid down that the power of arrest is the sole discretion of the police and it must be used only in exceptional cases. It held that denial of anticipatory bail does not

\footnotetext{
${ }^{22}$ A.I.R. 2006 S.C. 117.
}

${ }^{23}$ Vikram Ragahavan, Compensation Through Writ Petitions: An Analysis of Case Law, available at http://d.yimg.com/kq/groups/17293050/1027974966/ name/Compensation\%20through\%20writ\%20petitions\%20An\%20analysis\%20of $\% 20$ case\%20la (last visited Apr. 10, 2013).

${ }^{24}$ (2003) 2 S.C.C. 649. 
furnish a ground to arrest a person automatically. The power of arrest though absolute must be justified by the law. This decision of the Supreme Court was later upheld in the case of Som Mittal v. State of Karnataka. ${ }^{25}$ The court has interpreted the word 'may' that is used in the definition of a cognizable offence. As per this definition, a police officer 'may' arrest a person without a warrant. The court then held that as per this provision 'may' means merely 'may' and does not mean 'also'. When an arrest is made, justifications must be provided for the arrest. An arrest deprives an individual of his personal liberty. Thus, a balance must be struck between individual liberty and social interest. The court laid down that while on one hand the police is given the power of arrest on the other hand, the accused is given the right to get anticipatory bail in lieu of arrest.

In addition to granting anticipatory bail, the Supreme Court in a recent judgement specified the other alternatives to arrest. Elaborate guidelines were laid down so that the personal liberty of an individual is not curtailed. It has further stated that such illustrations were merely illustrative and not meant to be exhaustive. ${ }^{26}$ For instance, the accused can be first directed to join the investigation. If the court is of the opinion that accused has joined the investigation and in all probability will not abscond, then custodial interrogation should be avoided.27 Only if he does not cooperate should he be arrested. First a notice should be issued to the accused. If no heed is paid to the notice even after intimation, only then the police can arrest the accused. Instead of arrest, the police officer can seize the passport and other relevant documents and title deeds of property of the accused. The seizure of such documents prevents the accused from fleeing away and absconding from the police.

The police can also direct the accused to execute a bond of surety. This guideline has been issued so that the accused is prevented from tampering with the evidence or influencing the due course of justice. Furthermore, the court can direct bank accounts to be

25 (2008) 3 S.C.C. 753.

${ }^{26}$ Fulchand Gope v. State of Jharkhand, (2011) 12 S.C.C. 514.

${ }^{27}$ Siddharam Satlingappa Mhetre v. State of Maharashtra, (2010) 12 S.C.A.L.E. 691. 
frozen during investigation. This prevents the accused from taking his money from the bank account. The Supreme Court has stated that if police officer deems that the arrest is imperative after looking into the facts of the case, then the arresting officer must clearly record the reasons for the arrest. These compelling reasons must then be recorded in the case diary to ensure transparency. The court observed that the power of arrest must be exercised only in real and exceptional circumstances.

\section{Conclusion}

Timely judicial interventions have significantly contributed towards ensuring constitutional and procedural safeguards against arbitrary arrest. Personal liberty has been given predominance over the power of the executive to effectuate arrest through these decisions. Further, the amendments to CrPC 1973 also guarantee enhanced protection for arrested persons against custodial death, torture etc. This in turn has limited the power of the executive thereby securing the protection of the fundamental rights in the event of arrest. 